\title{
The role of oestrogen receptor beta (ERß) in the aetiology and treatment of type 2 diabetes mellitus
}

Wendy Amy Ofosu ${ }^{1}$, Dahir Mohamed ${ }^{1}$, Olivia Corcoran ${ }^{1}$ and Opeolu Oyejide Ojo ${ }^{1,2}$

$1=$ School of Health, Sport and Biosciences, College of Health and Communities, University of East London, Stratford, E15 4LZ, UK

${ }^{2}=$ School of Sciences, Faculty of Science and Engineering, University of Wolverhampton, Wolverhampton, WV1 1LY, UK

\section{Corresponding author(s):}

(1) Dr Opeolu O. Ojo, School of Health, Sport and Bioscience, University of East London, Stratford, E15 4LZ, UK, Email: o.o.ojo@uel.ac.uk; cecejyde@yahoo.com . Tel: +442082232473 .

(2) Professor Olivia Corcoran, Medicines Research Group, School of Health, Sport and Bioscience, University of East London, Stratford, E15 4LZ, UK, Email: o.corcoran@uel.ac.uk Tel: +442082234034

Running Title: The role of oestrogen receptor beta in glucose metabolism

Keywords: Oestrogen receptor, ER $\beta$, ER $\alpha$, GPER, insulin resistance, type 2 diabetes, GLUT4 


\begin{abstract}
Introduction: Challenges facing the treatment of type 2 diabetes necessitate the search for agents which act via alternative pathways to provide better therapeutic outcomes. Recently, an increasing body of evidence implicates the activation of oestrogen receptors (ER $\alpha$ and ER $\beta$ ) in the development and treatment of underlying conditions in type 2 diabetes. This article summarizes available evidence for the involvement of oestrogen receptors in insulin secretion, insulin resistance as well as glucose uptake and highlights the potential of ER $\beta$ as a therapeutic target.
\end{abstract}

Background: Recent studies indicate an association between the activation of each of the isoforms of ER and recent findings indicate that ER $\beta$ show promise as a potential target for antidiabetic drugs. In vitro and in vivo studies in receptor knock out mice indicate beneficial actions of selective agonists of ER $\beta$ receptor and underscore its therapeutic potential.

Conclusion: Studies are needed to further elucidate the exact mechanism underlying the role of ER $\beta$ activation as a therapeutic approach in the management of type 2 diabetes.

\title{
1.0 Introduction
}

Type 2 Diabetes (T2D) is a metabolic disease arising from failure in glucose homeostasis, caused either by impaired glucose secretion or defective insulin action. Normal insulin secretion begins with the uptake of glucose followed by a series of reactions culminating in the activation of the $\mathrm{K}_{\mathrm{ATP}}$-dependent or the CAMP-dependent pathway in pancreatic beta cells [1]. The release of insulin facilitates the uptake of glucose from the blood stream at target sites such as adipose tissue and skeletal muscles. In diabetes, this mechanism goes awry, leading to complications which affects the eye, kidney, heart and the nervous system [1-3]. Despite the heterogenic nature of the disease, it is hypothesised that insulin resistance, defined as the inability of insulin to act on peripheral tissues, is one of the major factors causing the disruption in glucose homeostasis [4]. This explains the renewed interest in developing novel therapeutic interventions which can correct defective insulin action. 


\subsection{Oestrogen receptors: structure and classical functions}

Oestrogen plays significant roles in the development and maintenance of reproductive functions, but has also been shown to play biologically significant roles in the nervous, immune, musculoskeletal and cardiovascular systems [5]. 17 $\beta$-estradiol (E2) has been reported as the most potent, endogenous agonist of oestrogen receptors (ERs) and its significant role in regulating the expression of these receptors is well established [6,7]. E2 diffuses through the cell to reach the nucleus and bind to the oestrogen receptor (ER). This complex mediates transcription by enabling the receptor to interact with oestrogen response elements (ERE) which are present in the promoter region of oestrogen-responsive genes. Thus, gene expression is regulated by recruiting activators or repressors and generating a cellular response.

The discovery of the first oestrogen receptor, ER $\alpha$, came in the 1960s when Elwood Jensen described the effects of an oestrogen binding protein [8]. Three decades later, ER $\alpha$ knockout mouse models revealed that ER $\alpha$ was not the sole mediator of oestrogen signalling. Further characterisation studies resulted in the discovery of the ER $\beta$ receptor, which was hypothesised to work as an alternative to substitute the knocked-out ER $\alpha$ receptor [9] and transmembrane ERs such as the G protein-coupled estrogen receptor (GPER), believed to have signalling and transcriptional regulatory roles [10]. However, it was studies involving $E R \alpha^{-/-}$and $E R \beta^{-/-}$and aromatase knock-out (ArKO) mouse models that helped elucidate the individual actions of ER $\alpha$ and $E R \beta$ receptors [11 - 13]. Aromatase gene is responsible for the endogenous production of E2 [14]. These models allowed a greater understanding of the distinct roles played by ER $\alpha$ and ER $\beta$ receptors in vivo. One of such studies investigated the differential mode of actions of the two receptors by studying their transfection into neuroblastomas. It was observed that transfected cells with activated ER $\alpha$ receptor had 
increased number and length of neurites whereas transfected cells with activated ER $\beta$ exhibited neurite elongation [15]. Moreover, Dupont et al [16] reported that while ER $\alpha$ is indispensable for ovulation and interstitial glandular cell development while ER $\beta$ is involved in ovarian follicle generation. In relation to insulin secretion, studies involving the use of agonists of both ER $\alpha$ and $E R \beta$ in ER $\alpha \mathrm{KO}$. ER $\beta \mathrm{KO}$ or wild type mice indicated that ER $\alpha$ is largely involved in the upregulation of pancreatic insulin content while the role of ER $\beta$ in this regard is not yet fully understood [17].

Moreover, the use of selective agonists for each class of receptors in cell lines which presented both ER $\alpha$ and ER $\beta$ produced different responses. Incubation of immortalized epithelial cell lines with selective ER $\alpha$ agonists resulted in cell proliferation whereas the use of selective ER $\beta$ agonists resulted in cell growth inhibition [18]. Different actions of ER $\alpha$ and ER $\beta$ at the promoters of the genes they regulate suggests that the global response of an agonist depends on the balance between the activities of both receptors [19] and opens the possibility for exploitation of these differential actions for selective therapies in the diseases involving oestrogen receptors.

\subsection{Roles of ERs in insulin secretion and glucose tolerance}

An increasing body of evidence indicates the involvement of oestrogen receptors (ER) in glucose homeostasis [14, 20-22]. ERs were first linked to obesity due to their expression in the adipose tissues. Studies in oestrogen receptor knock-out models further confirm the association between oestrogen receptors activation, insulin resistance and glucose homeostasis $[14,17,23]$. The activation of ER $\alpha$ by 17 beta-estradiol (E2) has been shown to stimulate insulin biosynthesis via a pathway involving the activation of ERK1 and ERK2 [24 - 26]. Nadal et al [26] further reported that hyperactivation of ER $\alpha$ by xenoestrogens (such as bisphenol A) can induce excessive insulin signalling, leading to insulin resistance. Following 
a study which investigated various mechanisms through which oestrogen receptors regulate glucose metabolism, Weigt et al [24] reported that the activation of ER $\alpha$ elicits muscular GLUT4 expression while the activation of ER $\beta$ leads to hypertrophy in muscle fibres. The observation of obesity and insulin resistance in aromatase gene knock-out (ArKO) mice further confirmed a role for $\operatorname{ER} \beta[25,26]$.

While severely impaired insulin sensitivity and glucose tolerance has been established in ER $\alpha$-knock out mice $[7,14,27,28]$, recent studies report a role for ER $\beta$ in glucose metabolism. For instance, ER $\beta$ isoform has been shown to be widely distributed and is the more dominant isoform found in skeletal muscle $[14,29,30]$, a site for glucose uptake. While aromatase deficiency and ER $\alpha$ polymorphisms have been associated with insulin resistance and type 2 diabetes [27], the role of ER $\beta$ in the development of type 2 diabetes is still unfolding. High-fat fed mice treated with ER $\beta$ selective agonist showed decreased expression of GLUT4 [30], the insulin-regulated glucose transporter found in adipose tissue and skeletal muscle, as well as impaired insulin sensitivity and glucose tolerance [31]. These effects are opposite to actions reported for ER $\alpha[30]$.

Studies have shown that oestrogen interacts with receptors in the plasma membrane as well as in the nucleus; eliciting both non-genomic and genomic responses respectively [32]. Though most genomic actions of oestrogen are generally believed to be consequences of the interaction of oestrogen with nuclear receptors, it has been reported that changes in gene expression can also result from oestrogen signalling via membrane-bound receptors [32, 33]. Though mechanisms underlying these actions are currently poorly understood and the membrane expression of ER $\alpha$ and ER $\beta$ in small quantities has been reported [34], G protein coupled ERs (GPER) have been largely implicated in this regard [33]. It has been reported that signalling through GPER is dependent on epidermal growth factor receptor and ERK 
activation via the actions of nonreceptor tyrosine kinases of the Src family [35, 36]. Prossnitz and Barton [36] further reported that GPER's activation by E2 leads to cAMP production, intracellular calcium recruitment and PI3K activation. These processes are critically involved in insulin secretion from beta cells and have attendant effects on glucose metabolism. This may also partly account for available evidence for the actions of oestrogens on cellular activities leading to the elevation of intracellular calcium concentration, NO production and the activation of kinases [37]. The involvement of oestrogens in these processes suggest involvement in the short-term regulation of metabolism and homeostasis.

\subsection{ERß activation, GLUT4 expression and implications for the treatment of type 2}

\section{diabetes}

Recent studies have shown that the activation of the ER $\beta$ triggers the closure of the ATPsensitive potassium channel ( $\mathrm{K}_{\mathrm{ATP}}$-channel) leading to membrane depolarization, the opening of the voltage dependent calcium channel (VDCC), influx of extracellular calcium and insulin secretion in a glucose-dependent manner $[5,38]$. Other studies demonstrated that E2 increases the level of cyclic GMP (cGMP) in pancreatic beta cells. This promotes the recruitment of intracellular calcium resulting in increased insulin secretion in pancreatic beta cells [39]. These actions strongly suggest a role for ER $\beta$ in the cascade of events leading to physiologic insulin secretion and the potential use of ER $\beta$ receptor agonists in the treatment of type 2 diabetes. Effects observed in in vitro studies were also investigated in in vivo. Alonso-Magdalena et al. [5] reported both acute and chronic beneficial actions of a novel ER $\beta$ selective agonist, WAY200070, on insulin secretion and glucose tolerance in mice with chemically-induced type 2 diabetes. A major conclusion of studies investigating anti-diabetic actions of ER agonists is that effects observed are largely dependent on cellular ER $\alpha$ :ER $\beta$ expression ratio and that further studies are needed to explain the interplay between the differential expression of these receptors vis-à-vis their role in glucose metabolism $[5,30]$. 
Evidence for GLUT4 modulation by ER $\beta$ could provide a possible avenue for the treatment of diabetes mellitus. Investigations, aimed at evaluating the effects of E2 on GLUT 4 subcellular localization or expression, conducted on white adipose tissue were less successful compared to studies which analysed ER expression in mice skeletal muscle. Barros et al. [40], for instance, observed the co-localization of ER $\alpha$ and $\operatorname{ER} \beta$ in the nuclei of gastrocnemius muscle in mice and argued that E2 activity is a function of the ratio at which $\mathrm{ER} \alpha$ and ER $\beta$ are expressed in the tissue. The study also indicated that ER $\alpha: E R \beta$ ratio influences GLUT 4 expression and its sub-cellular localization. In a study conducted using ArKO mice, Barros et al. [40] showed that GLUT4 was dually modulated and that treatment with an ER $\beta$ agonist, 2,3-bis(4-hydroxyphenyl)propionitrile (DPN) elicited blunted GLUT4 expression. Though no overall conclusion can be made about whether this is a general characteristic of all ER $\beta$ ligands [41, 42], this observation partly informed the current understanding that the inhibition of ER $\beta$ (e.g. by using an antagonist of ER $\beta$ expression), could result in changes to ER $\alpha: E R \beta$ ratios in cells where they are co-expressed (such as skeletal muscle and adipose tissue [43]). These observations indicate a GLUT4-modulatory role for ER $\beta$ and suggest that the receptor could be an important therapeutic target for type 2 diabetes.

Endogenous regulation of ER $\beta$ levels in skeletal muscle by steroid hormone, androgen, plays significant roles in the modulation of muscle physiology leading to decreased ER $\beta$ expression and subsequent inhibition of insulin resistance [40]. Association between insulin resistance and diabetes mellitus in hypogonadal patients with low levels of testosterone, a hormone previously shown to down regulate ER $\beta$ activity, has also been established [44, 45]. Previous observations together with the discovery of novel agonists of ER $\beta$ (such as 4(butyryloxy)benzoate) point towards the importance of producing tissue-specific selective ER $\beta$ modulators as alternate potential therapeutic agents for the treatment of type 2 diabetes 
[46]. Tetrahydrochrysene (R,R-THC) is another promising agent which acts as a selective $\mathrm{ER} \alpha$ agonist and $\mathrm{ER} \beta$ antagonist [46].

The production of drugs which selectively target transcription factors regulating GLUT4 expression, such as nuclear factor $\kappa \mathrm{B}$ response element $(\mathrm{NF}-\kappa \mathrm{B}-\mathrm{RE})$ and specificity protein 1 (SP1), represents another therapeutic approach in this regard [47, 48]. The activation of ER $\alpha$ and ER $\beta$ have been demonstrated influence the actions of SP1 resulting in differing GLUT4 expression levels. However, these actions are both gene specific and variable in nature [49, 50]. It is hypothesised that ER $\alpha$ works to upregulate SP1 action resulting in increased GLUT4 expression whereas ER $\beta$ works to inhibit the action of SP1. However, the exact mechanism by which this is achieved is yet to be full elucidated.

\subsection{Conclusion}

In conclusion, improved understanding of the regulatory effects of estradiol (E2) on the expression of GLUT4 via interactions with ER $\alpha$ and/or ER $\beta$ may represents a significant milestone in the search for pathways involved in glucose homeostasis and insulin resistance. Available information clearly indicates the potential beneficial effects of selective activation of the ER $\beta$ as a target for the treatment of type 2 diabetes. However, there is a need for careful study of the underlying mechanism of action and other attendant effects of ER $\beta$ receptor agonists.

\subsection{Conflict of interests}

Authors declare no conflict of interests. WAO is funded by HSB PhD Research Studentship of the University of East London 


\section{References}

[1] Stumvoll, M.; Goldstein, B.J.; Van Haeften, T.W. Type 2 diabetes: principles of pathogenesis and therapy. Lancet, 2005, 365 (9467), 1333-13346.

[2] Alberti, K.G.; Zimmet, P.; Shaw, J. The metabolic syndrome - a new worldwide definition. Lancet, 2005, 366, $1059-1062$.

[3] Kahn, S.E.; Cooper, M.E.; Del Prato, S. Pathophysiology and treatment of Type 2 Diabetes: Perspectives on the past, present and future. Lancet. 2014, 383(9922), $1068-1083$

[4] Bjornholm, M.; Zierath, J.R. Insulin signal transduction in human skeletal muscle: identifying the defects in Type II diabetes. Biochem. Soc. Trans., 2005, 33, 354357

[5] Alonso-Magdalena, P.; Ropero, A.B.; García-Arévalo, M.; Soriano, S.; Quesada, I.; Muhammed, S.J.; Salehi, A.; Gustafsson, J.A.; Nadal, A. Antidiabetic actions of an estrogen receptor $\beta$ selective agonist. Diabetes., 2013, 62(6), :2015-2025

[6] Chambon, P. The nuclear receptor superfamily: a personal retrospect on the first two decades. Mol. Endocrinol., 2005, 19, 1418-1428

[7] Bryzgalova, G.; Gao, H.; Ahren, B.; Zierath, J.R.; Galuska, D.; Steiler, T.L.; Dahlman-Wright, K.; Nilsson, S.; Gustafsson, J.A.; Efendic, S.; Khan, A. Evidence that oestrogen receptor-alpha plays an important role in the regulation of glucose homeostasis in mice: insulin sensitivity in the liver. Diabetologia, 2006, 49(3), 588-597

[8] Jensen, E.V. On the mechanism of estrogen action. Perspect Biol. Med., 1962, 6, $47-54$

[9] Kuiper, G.G.; Enmark, E.; Pelto-Huikko, M.; Nilsson, S.; Gustafsson, J.A. Cloning of a novel receptor expressed in rat prostate and ovary. Proc Natl Acad Sci USA, 1996, 93, 5925-5930.

[10] Prossnitz, E.R.; Barton, M. The G-protein-coupled estrogen receptor GPER in health and disease. Nat. Rev. Endocrinol., 2011, 7(12):715-726

[11] Krege, J.H.; Hodgin, J.B.; Couse, J.F.; Enmark, E.; Warner, M.; Mahler, J.F.; Sar, M.; Korach, K.S.; Gustafsson, J.A.; Smithies, O. Generation and reproductive 
phenotypes of mice lacking estrogen receptor beta. Proc Natl Acad Sci USA, 1998, 95(26), 15677-15682

[12] McDevitt, M.A.; Glidewell-Kenney, C.; Jimenez, M.A.; Ahearn, P.C.; Weiss, J.; Jameson, J.L.; Levine, J.E. New insights into the classical and non-classical actions of estrogen: evidence from estrogen receptor knock-out and knock-in mice. Mol. Cell. Endocrinol., 2008, 290(1), 24-30

[13] Jones, M.E.; Thorburn, A.W.; Britt, K.L.; Hewitt, K.N.; Wreford, N.G.; Proietto, J., Oz, O.K.; Leury, B.J.; Robertson, K.M.; Yao, S.; Simpson, E.R. Aromatasedeficient (ArKO) mice have a phenotype of increased adiposity. Proc. Natl. Acad. Sci. U.S.A., 2000, 97(23), 12735-12740

[14] Barros, R.P.; Gustafsson, J.A. Estrogen receptors and the metabolic network. Cell Metab., 2011, 14(3), 289-299

[15] Patrone, C.; Pollio, G.; Vegeto E, Enmark E, de Curtis I, Gustafsson JA, Maggi A. Estradiol induces differential neuronal phenotypes by activating estrogen receptor alpha or beta. Endocrinology, 2000,141(5), 1839-1845

[16] Dupont, S.; Krust, A.; Gansmuller, A.; Dierich, A.; Chambon, P.; Mark, M. Effect of single and compound knockouts of estrogen receptors alpha (ERalpha) and beta (ERbeta) on mouse reproductive phenotypes. Development, 2000, 127(19), 42774291

[17] Alonso-Magdalena, P.; Ropero, A.B.; Carrera, M.P.; Cederroth, C.R.; Baquie, M.; Gauthier, B.R.; Nef, S.; Stefani, E.;, Nadal, A. Pancreatic insulin content regulation by the estrogen receptor ER $\alpha$. PloS One, 2008, 3(4), e2069

[18] Helguero, L.A.; Faulds, M.H.; Gustafsson, J.A.; Haldosén, L.A. Estrogen receptors alpha $(E R \alpha)$ and beta $(E R \beta)$ differentially regulate proliferation and apoptosis of the normal murine mammary epithelial cell line HC11. Oncogene, 2005, 24, 66056616

[19] Heldring, N.; Pike, A.; Andersson, S.; Matthews, J.; Cheng, G.; Hartman, J.; Tujague, M.; Stro“m, A.; Treuter, E.; Warner, M.; Gustafsson, J.A. Estrogen receptors: how do they signal and what are their targets. Physiol Rev., 2007, 87, 905-931

[20] Nilsson, S.; Makela, S.; Treuter, E.; Tujague, M.; Thomsen, J.; Andersson, G.; Enmark, E.; Pettersson, K.; Warner, M.; Gustafsson, J.Å. Mechanisms of estrogen action. Physiol Rev., 2001, 81:1535-1565 
[21] Alonso-Magdalena, P.; Ropero, A.B.; Carrera, M.P.; Cederroth, C.R.; Baquie,' M.; Gauthier, B.R.; Nef, S.; Stefani, E.; Nadal, A. Pancreatic Insulin Content Regulation by the Estrogen Receptor ERa. PLoS One, 2008, 3(4), e2069.

[22] Ropero, A.B.; Alonso-Magdalena, P.; Quesada, I.; Nadal, A. The role of estrogen receptors in the control of energy and glucose homeostasis. Steroids, 2008, 31, 73(9), 874-879

[23] Jones, M.E.; Thorburn, A.W.; Britt, K.L.; Hewitt, K.N.; Wreford, N.G.; Proietto, J.; Oz, O.K.; Leury, B.J.; Robertson, K.M.; Yao, S.; Simpson, E.R. Aromatasedeficient (ArKO) mice have a phenotype of increased adiposity. Proc Natl Acad Sci USA, 2000, 97, 12735-12740

[24] Weigt, C.; Hertrampf, T.; Flenker, U.; Hülsemann, F.; Kurnaz, P.; Fritzemeier, K.H.; Diel, P. Effects of estradiol, estrogen receptor subtype-selective agonists and genistein on glucose metabolism in leptin resistant female Zucker diabetic fatty (ZDF) rats. J. Steroid Biochem. Mol. Biol., 2015, 154, 12-22.

[25] Takeda, K.; Toda, K.; Saibara, T.; Nakagawa, M.; Saika, K.; Onishi, T.; Sugiura, T.; Shizuta, Y. Progressive development of insulin resistance phenotype in male mice with complete aromatase (CYP19) deficiency. J Endocrinol., 2003, 176, 237246.

[26] Nadal, A.; Alonso-Magdalena, P.; Soriano, S.; Quesada, I.; Ropero, A.B. The pancreatic beta-cell as a target of estrogens and xenoestrogens: Implications for blood glucose homeostasis and diabetes. Mol Cell Endocrinol., 2009. 304(1-2), 6368

[27] Koehler, K.F.; Helguero, L.A.; Haldosén, L.A.; Warner, M.; Gustafsson, J.A. Reflections on the discovery and significance of estrogen receptor beta. Endocr Rev., 2005, 26(3), 465-478

[28] Bansal, S.; Chopra, K. Distinct role of estrogen receptor-alpha and beta on postmenopausal diabetes-induced vascular dysfunction. Gen. Com. Endocrinol., 2014, 206, 51-59.

[29] Barros, R.P.; Gabbi, C.; Morani, A.; Warner, M.; Gustafsson, J.A. Participation of ERalpha and ERbeta in glucose homeostasis in skeletal muscle and white adipose tissue. Am J Physiol Endocrinol Metab., 2009, 297(1), E124-E133

[30] Barros, R.P.; Machado, U.F.; Gustafsson, J.A. Estrogen receptors: new players in diabetes mellitus. Trends Mol. Med., 2006, 12, 425-431 
[31] Foryst-Ludwig, A.; Clemenz, M.; Hohmann, S.; Hartge, M.; Sprang, C.; Frost, N.; Krikov, M.; Bhanot, S.; Barros, R.; Morani, A.; Gustafsson, J.A.; Unger, T.; Kintscher, U. Metabolic actions of estrogen receptor beta (ERbeta) are mediated by a negative cross-talk with PPARgamma. PLoS Genet., 2008, 4(6), e1000108

[32] Pedram, A.; Razandi, M.; Aitkenhead, M,; Hughes, C.C.; Levin, E.R. Integration of the non-genomic and genomic actions of estrogen membrane-initiated signaling by steroid to transcription and cell biology. J Biol Chem., 2002, 277(52), 5076850775

[33] Wyckoff, M.H.; Chambliss, K.L.; Mineo, C.; Yuhanna, I.S.; Mendelsohn, M.E.; Mumby, S.M.; Shaul, P.W. Plasma membrane estrogen receptors are coupled to endothelial nitric-oxide synthase through Gai. J. Biol. Chem., 2001, 276(29), 27071-27076.

[34] Razandi, M.; Pedram, A.; Greene, G.L.; Levin, E.R. Cell membrane and nuclear estrogen receptors (ERs) originate from a single transcript: studies of ER $\alpha$ and ER $\beta$ expressed in Chinese hamster ovary cells. Mol. Endocrinol., 1999, 3(2), 307-319

[35] Sharma, G.; Prossnitz, E.R. Mechanisms of estradiol-induced insulin secretion by the $G$ protein-coupled estrogen receptor GPR30/GPER in pancreatic $\beta$-cells. Endocrinology., 2011, 152(8), 3030-3039.

[36] Prossnitz, E.R.; Barton, M. The G-protein-coupled estrogen receptor GPER in health and disease. Nat. Rev. Endocrinol., 2011, 7(12), 715-726.

[37] Deroo BJ, Korach KS. Estrogen receptors and human disease. J Clin Invest. 2006; 116(3):561-70.

[38] Soriano, S.; Ropero. A.B.; Alonso-Magdalena, P.; Ripoll, C.; Quesada, I.; Gassner, B.; Kuhn, M.; Gustafsson, J.A.; Nadal, A. Rapid regulation of K(ATP) channel activity by 17 \{beta\}-estradiol in pancreatic \{beta\}-cells involves the estrogen receptor $\{$ beta $\}$ and the atrial natriuretic peptide receptor. Mol Endocrinol., 2009, 23(12), 1973-1982

[39] Ropero, A.B.; Fuentes, E.; Rovira, J.M.; Ripoll, C.; Soria, B.; Nadal, A. Non genomic actions of $17 \beta$ cGMP

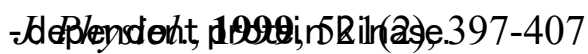

[40] Barros, R.P.; Machado, U.F.; Warner, M.; Gustafsson, J.A. Muscle GLUT4 regulation by estrogen receptors ERbeta and ERalpha. Proc Natl Acad Sci USA, 2006, 103(5), 1605-1608. 
[41] Follettie, M.T.; Pinard, M.; Keith, J.C.; Wang, L.; Chelsky, D.; Hayward, C.; Kearney, P.; Thibault, P.; Paramithiotis, E.; Dorner, A.J.; Harris, H.A. Organ messenger ribonucleic acid and plasma proteome changes in the adjuvant-induced arthritis model: responses to disease induction and therapy with the estrogen receptor- $\beta$ selective agonist ERB-041. Endocrinology, 2006, 147(2), 714-723

[42] Komm, B.S.; Kharode, Y.P.; Bodine, P.V.; Harris, H.A.; Miller, C.P.; Lyttle, C.R. Bazedoxifene acetate: a selective estrogen receptor modulator with improved selectivity. Endocrinology, 2005, 146(9), 3999-4008.

[43] Park, Y.M.; Pereira, R.I.; Erickson, CB.; Swibas, T.A.; Cox-York, K.A.; Van Pelt, RE. Estradiol-mediated improvements in adipose tissue insulin sensitivity are related to the balance of adipose tissue estrogen receptor $\alpha$ and $\beta$ in postmenopausal women. PloS One., 2017, 12(5), e0176446.

[44] Pitteloud, N.; Hardin, M.; Dwyer, AA.; Valassi, E.; Yialamas, M.; Elahi, D.; Hayes, FJ. Increasing insulin resistance is associated with a decrease in Leydig cell testosterone secretion in men. J Clin Endocrinol Metab. 2005, 90(5), 26362641

[45] Lin, Z.; Shen, H.; Huang, J.; Chen, S.; Chen, L.; Chen, J.; Liu, G.; Jiang, H.; Shen, $\mathrm{X}$. Butyl 4-(butyryloxy)benzoate functions as a new selective estrogen receptor beta agonist and induces GLUT4 expression in CHO-K1 cells. J Steroid Biochem Mol Biol., 2008, 110(1-2), 150-156

[46] Harrington, W.R.; Sheng, S.; Barnett, D.H.; Petz, L.N.; Katzenellenbogen, J.A.; Katzenellenbogen, B.S. Activities of estrogen receptor - and -selective ligands at diverse estrogen responsive gene sites mediating transactivation or transrepression. Mol Cell Endocrinol, 2003. 206, 13-22

[47] Kaestner, KH.; Christy, RJ.; Lane, M.D. Mouse insulin-responsive glucose transporter gene: Characterization of the gene and trans-activation by the CCAAT/enhancer binding protein. Proc. Natl. Acad. Sci. USA., 1990, 87, 251-255

[48] Long, S.D.; Pekala, P.H. Lipid mediators of insulin resistance: ceramide signalling down-regulates GLUT4 gene transcription in 3T3-L1 adipocytes. Biochem. J., 1996, 319, 179-184

[49] Kanda, N.; Watanabe, S. 17b-estradiol inhibits MCP-1 production in human keratinocytes. J. Invest. Dermatol., 2003, 120, 1058-1066

[50] Salvatori, L.; Pallante, P.; Ravenna, L.; Chinzari, P.; Frati, L.; Russo, M.A.; Petrangeli, E. Oestrogens and selective oestrogen receptor (ER) modulators 
regulate EGF receptor gene expression through human ER $\alpha$ and $\beta$ subtypes via an Sp1 site. Oncogene., 2003, 22:4875-4881 